\title{
The Role of Trust, Relationships and Professional Ethics in the Supply of External Business Advice by Accountants to SMEs ${ }^{1}$
}

\author{
Robert Blackburn², Peter Carey and George A. Tanewski ${ }^{3}$
}

\begin{abstract}
The accounting profession has actively adopted a broader service focus which includes business advice, but the scant extant research in the SME environment identifies only exante demand determinants. Using in-depth interviews with SME owner-managers and external accountants, this study confirms the intervening role of trust, relationships, and professional ethics in the enabling of the provision of business advice. All SMEs purchase business advice, but not all use their external accountant. While all accountants interviewed perceived they have the expertise to provide business advice, not all SMEs agreed, suggestive of an expectation gap. However, when an SME does purchase business advice from their accountant, they view them as a business expert, a "trusted partner", and a confidante who has empathy and provides a personal relationship to the owner-manager. Accountants do not aggressively market their business expertise, instead relying primarily on relationships formed while providing compliance work, "milestone events" or from SME networks or forums. An implication is the need for debate whether accountants should overtly market their non-compliance services.
\end{abstract}

\footnotetext{
${ }^{1}$ We would like to thank a number of bodies and individuals without which it would not have been possible to undertake this research. We would like to thank the ACCA for funding the project and providing us with guidance and advice on various stages of the research. We also like to thank the business owner-managers, accountants and financial advisers for giving up their valuable time to be interviewed and providing us with some fascinating evidence on which this report is based. A special acknowledgement should go to William Peppard who patiently synthesized all interview transcripts and prepared the first draft of the results section. Earlier drafts of the paper benefitted from the feedback kindly provided by peer reviewers. Any errors or omissions in the paper remain the responsibility of the authors.

${ }^{2}$ Professor Robert Blackburn, Director of Research, Faculty of Business and Law, Kingston University, Kingston Hill, Kingston Upon Thames, Surrey, KT2 7LB, UK. Email: r.blackburn@kingston.ac.uk

${ }^{3}$ Associate Professor Peter Carey and Associate Professor George Tanewski, Department of Accounting and Finance, Faculty of Business and Economics, Monash University. Address for correspondence: Associate Professor George Tanewski, Department of Accounting and Finance, Faculty of Business and Economics, Monash University, PO Box 197, VIC, 3145, Australia Tel: 61-3-99032388; Fax: 61-3-9903-2422

Email: george.tanewski@buseco.monash.edu.au peter.carey@buseco.monash.edu.au
} 


\section{INTRODUCTION}

While external accountants have expanded their services to include more broad ranging business advice, few studies have investigated this emerging market in the SME environment. ${ }^{4}$ Previous studies find extensive use of external accounting services by SMEs (e.g. Bennett and Robson, 1999; Carey et al., 2005; Doving and Gooderham, 2008;

Gooderham et al. 2004; Carey and Tanewski, 2009). Indeed, accountants are the most frequently used source of external advice, ahead of banks solicitors and public sector providers (Bennett and Robson, 1999; Carey et al., 2005; BIS, 2009). Research shows that external accountants have expanded their service offerings, to include a broad range of business advisory services, supporting a range of information needs serving both external and internal stakeholders (Fogarty et al. 2006; Greenwood et al. 2002). The few studies that have explored the determinants of advisory services in the SME environment find only a limited number of antecedent factors associated with business advice (e.g., competence of accountant, size of firm, industry, and firm growth) (see for example Carey and Tanewski 2009; Gooderham et al. 2004; Bennett and Robson, 1999; Kirby et al. 1998). This underdeveloped literature is largely descriptive and provides only limited insight into the exchange of business advice. A number of studies have conjectured that the determinants of business advice are more complex involving trust, relationships and professional ethics in the provision of business advice (e.g., Bennett and Robson, 1999, 2001; Gooderham et al. 2004; Kirby et al. 1998; Carey and Tanewski 2009). The primary objectives of this research are to present a framework and explore the intervening role of trust, relationships, and professional ethics in the supply of business advice to SME clients, as well as uncovering other factors that may influence SMEs purchase of business advice using exploratory qualitative research techniques.

For decades external accountants have provided historically-oriented compliance and monitoring services (e.g., taxation, compilation and audit) designed around regulatory requirements or to satisfy either statutory or voluntary contractual constraints (Parker, 2001;

\footnotetext{
${ }^{4}$ The definition of a 'Small and Medium Sized Enterprise' (SME) in the Australian context is derived from the Australian Bureau of Statistics (ABS) as businesses with 5 to 200 employees. The ABS defines a micro business as $<5$ employees, a small business as 5-19 employees and a medium sized business as 20 to 200 employees. In the United Kingdom, a SME is defined as a business that employs less than 250 people, a micro business as $<10$ employees, a small business 10-49 and a medium sized business as 50-249 (see Department for Business Innovation and Skills, 2009).
} 
Carey and Tanewski, 2009). These 'traditional' services typically focus on the preparation or interpretation of financial data within existing rules and standardised formats (e.g., GAAP). However, since the 1980s external accountants have expanded their range of monitoring and advisory services, to support a broader range of information needs in recognition of the emerging requirements of businesses (Greenwood et al., 2002). Consequently accountants have developed multi-disciplinary practices offering a more diverse range of skills and services to provide support to organizations that are increasingly demanding services and products more tailored to their needs with speed, quality and personalized attention (Fogarty et al. 2006; Greenwood et al. 2002; Parker 2001).

While maintaining its traditional focus, the accounting profession has increasingly represented its members as business advisers, with the view of 'adding value' to the client (Fogarty et al. 2006; Berry et al. 2006; Greenwood et al. 2002). This has been bolstered by the fact that the 'bread and butter' of many small accountancy practices has diminished through more extensive use of computer technology and the growth in audit exemptions (particularly in the UK) which has resulted in accountants actively seeking to widen their portfolio of services (Ram and Carter, 2001). An example of the broader range of services offered by external accountants is provided by Martin (2004), who finds that accountants have developed expertise in the provision of succession advice, and whilst much of this is financially related, research suggests that this goes beyond conventional taxation and financial issues, including, business development advice and 'emotional' support.

The emerging category of business advisory service or business advice (i.e., management consulting or NAS) is designed primarily to assist in the management of the firm, rather than directly servicing the needs of external stakeholders. Hence this study adopts the term 'business advice' to mean those professional services, provided by accountants, that assist or advise clients in the strategic direction and operational running of the firm. This may involve acquisitions; wealth management and investments; corporate finance; cash-flow planning; succession; review of systems; human resource issues; and payroll.

While the accounting profession has long promoted the benefit of external accountants providing business advice, the empirical research does not provide a complete explanation of the emerging market for business advice. A number of researchers have highlighted that an understanding of relational exchange of business advice is a complex 
phenomenon involving the intervening impact of trust, relationships and professional ethics (e.g., Bennett and Robson, 1999, 2001; Gooderham et al. 2004; Kirby et al. 1998; Carey and Tanewski 2009). Using in-depth interviews with SME owner managers and external accountants the objectives of this research are to provide a detailed understanding of the nature of services provided by accountants to SMEs and to explore the intervening role of trust, relationships and professional ethics in the market for business advice.

The remainder of this paper is organized as follows: Section 2 provides a conceptual framework for business advice. Section 3 provides an explanation of the research methods used in the study, followed by an exposition of the results in sections 4 and 5, and conclusions, implications and recommendations in Section 6.

\section{A CONCEPTUAL FRAMEWORK FOR BUSINESS ADVICE}

While the accounting profession has actively adopted a broader service focus which includes business advice, extant research does not provide a generally accepted conceptual framework which explains the determinants of demand and supply for such voluntary professional accounting services. The following sections outline the main theories used in the literature to explain the emerging market for business advice. This is followed by a discussion on the intervening role of trust, relationships, and professional ethics in the provision of business advice by external accountants.

2.1. Ex-Ante Demand Characteristics of Business Advice - The resource-based approach is the most commonly used framework to explain the source of demand of business advice (e.g., Carey and Tanewski, 2009; Johnson et al., 2007; Gooderham et al., 2004). This approach focuses on the source of a firms' competitive advantage as the basis for business success and how the firm can maximize its value by combining and using all available resources to it (Barney, 1991, 2001). External advice can encapsulate a range of competencies that support the SME's intangible resources, providing a potential source of competitive advantage (Gooderham et al. 2004). A firm might engage their external accountant to provide advice which directly assists performance (e.g., strategic advice on growing revenue) or advice that has an indirect impact on performance such as advice directed at improving management control (e.g., advice on regulatory compliance, risk, systems, performance reviews) finance 
structure (introducing sources of finance) or financial planning (insurance, investment, superannuation). With their long-standing expertise in systems and matters of finance, the external accountant might aid their SME client to achieve competitive advantage.

A number of characteristics which proxy for SME demand for business advice are derived from the resource-bases approach. These characteristics are summarised in the first column of Figure 1 "Ex-Ante Demand for Business Advice". The first characteristic refers to size of the firm whereby larger firms are more likely to purchase business advice. Larger firms command a competitive advantage in securing resources (Johnson et al. 2007; Gooderham et al. 2004).

This is despite the often held assumption that smaller firms may have a greater need for advice because they often lack important skills such as knowledge of financial controls (Deakins et al 2001) and have difficulty obtaining and retaining competent staff because of their inability to offer competitive salaries and benefits (Jennings and Beaver 1997). The age of the firm will influence the likelihood that an SME will source business advice. The external accountant is an important source of advice during the early stage of the business development as the owner navigates the unfamiliar regulatory and operational challenges (Deakins et al. 2002; Johnson et al. (2007). An SME is particularly vulnerable to failure in their early years (e.g, Peacock 1986; Perry and Pendelton 1983; BIS, 2009), creating incentives for SME management SME to seek advice from their external accountant.

Holmes et al. (1991) conjecture that small firms seek external support only when a 'crisis point' is reached. SMEs facing heightened financial risk have incentive to seek advice from their external accountants to source resources that assist in overcoming financial difficulties (i.e., on financial management to aid in overcoming their financial difficulties). ${ }^{5}$ Proxies measuring financial risk include gearing and a history of loss making. Businesses that intend to grow are more likely than others to need (and hence benefit from) external advice or support because they are likely to provide a challenge to the internal resources and knowledge base of the SME firm, most obviously in relation to the managerial skills and capacities of the owner-manager (Johnson et al. 2007; Kitching and Blackburn, 2002; Blackburn et al., 2006; Gooderham et al. 2004). Firth (1997) and Houghton and Ikin (2001) argue that businesses planning to restructure are more likely to source externally provided

\footnotetext{
${ }^{5}$ A competing argument is that facing heightened financial risk SMEs are more financially stretched and thus less able to afford to buy business advice from their external accountant.
} 
$\underline{\text { Ex-Ante Demand for Business Advice }}$

Size of Firm

Age of Firm

\section{Gearing}

Loss

Financial \}

Intention to Grow

Restructure

$\begin{array}{ll}\text { Competition } & \text { External Conditions } \\ \text { / Factors }\end{array}$

Board of Directors 7 Resources

In-House Accountant $\}$ Available to the

Industry

\section{Intervening Factors}

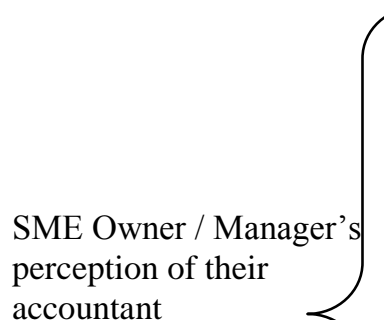

accountant

\section{Trust, Competence and Professional Ethics}

1. Trust

- Integrity

- Benevolence / Empathy

- Ability / Competence

2. Other Attributes of Professional Ethics

- Confidentiality

- Objectivity

- Independence

3.Relationship Marketing

- Social Rapport

- Understanding business needs

\section{Other Intervening Factors}

4. Perceived Value of Service

- Satisfaction with service

- Value for money

5. Financial Benefit 4. Salesperson

- Good Salesperson

- Proactive marketing

\section{Dependent Variable}

Purchase of Non-

Statutory / Non-

Compliance Business

Advice

Figure 1. A Conceptual Framework for Business Advice 
consultancies. In a more competitive business environment firms have greater incentives to access advice as a source of competitive advantage (Gooderham et al. 2004). Other explanatory characteristics measuring whether firms use the external accountant to overcome resource constraints include the total number of directors and whether the SME employs an external accountant. With more members on the board of directors and an in-house accountant, advice is likely to be sourced in-house from the resources available rather than from an external accountant (Carey and Tanewski, 2009). Demand for business advice will vary between different industries. Bennett and Robson (1999) identify that greater SME demand for business advice is observed in the manufacturing sector.

Empirical findings concerning these demand characteristics are mixed. Factors found to be associated with voluntary demand for business advice in the SME environment are size (Carey and Tanewski 2009; Bennett and Robson 1999), intention to grow the business (Carey and Tanewski 2009; Cassar and Ittner 2008; Chell and Baines 2000), size of the board of directors (Carey and Tanewski, 2009), employment of an in-house accountant (Carey and Tanweski, 2009).

2.2. Intervening Factors: Trust, Relationships and Professional Ethics - The primary objective of this paper is to investigate the intervening role of trust, relationships and professional ethics in the exchange of business advice in the SME environment. While the characteristics described in the previous section explain ex-ante or latent demand by SMEs, this section discusses the unexplored role that trust, relationships and professional ethics play in enabling (intervening) business advice exchanges between clients and external accountants. These factors listed in column 2 of Figure 1 influence the propensity of an SME to purchase business advice. While the demand factors will determine an SME's ex-ante need for advice, these intervening factors determine whether business advice is realised.

Extant literature on the motivations and reasons exploring owner-managers engagement with external organisations for trade, advice and support, either implicitly or explicitly, refer to notions of 'trust' (e.g., Bennett and Robson, 1999). It appears trust is developed through ongoing relationships, it is established over time, between parties to facilitate better understanding of mutual needs, competencies and to assist in minimising potential uncertainties (Carey and Tanewski, 2009). Trust has been argued to reduce 
transaction costs (Andaleeb, 1992), is proposed to be a source of competitive advantage (Barney and Hansen, 1994) and it limits uncertainty and opportunism (Achrol, 1997).

This study adopts a definition of trust derived by Mayer et al. (1995), who asserts that trust comprises ability (competence), integrity, and empathy (benevolence) (Figure 1 reflects this definition of trust). Ability (competence) is the degree to which SME clients perceive their external accountant possesses the skills and knowledge to provide advice. Competence is defined as the degree to which SME clients perceive that the business adviser possesses the required skills and knowledge to supply professional advice, while reliability and promptness refer to the delivery of professional advice in a dependable and timely manner (Parasuraman et al., 1985). Integrity is the extent to which the SME owner-manager believes the external accountant will adhere to a set of principles which they accept (i.e., the code of ethics for professional accountants). Empathy (benevolence) is the extent to which the SME client perceives that the external accountant will act in their best interests, i.e., understanding and genuinely caring about the clients' business and personal needs. Empathy is defined as the degree which the business adviser possesses a "warm, considerate, and caring" attitude (Parasuraman et al., 1988). ${ }^{6}$

The marketing literature similarly documents that service relationships evolve during specific service encounters (Price et al., 1995) and they become established over time (Crosby et al. 1990) while a client acquires information and a good understanding of their service provider. The term 'relationship marketing' (Berry, 1983) focuses on the recognition that existing customer (supplier) relationships are assets that can be managed to improve customer retention and profitability (Ryals and Payne 2001). Central to successful relationship marketing is knowledge of the client (customer) combined with social rapport (Ryals and Payne 2001; Hennig-Thurau 2000). While understanding client needs is closely

\footnotetext{
${ }^{6}$ There are many alternative definitions of trust in the literature, for example: Perceived trustworthiness encompasses both cognitive and affective (or emotional) beliefs that one party will not exploit another's vulnerability (Anderson and Weitz, 1989; Tyler and Stanley, 2007). Indeed, Möllering (2002) argues that perceived trustworthiness is ultimately cognised through '...the eyes of the beholder' (p. 140); Trusting behaviour - actions that incline one party towards risk, uncertainty or vulnerability to another whose behaviour is not under one's control (Zand, 1972; Tyler and Stanley, 2007); Trust as a behavioural intention or reliance on a partner - in light of this dimension, Moorman et al., (1993, p. 82) defines trust as the "willingness to rely on a partner in whom one has confidence"; Trust as vulnerability and willingness to take risks - by differentiating trust from cooperation, confidence, and predictability as well as considering the characteristics of the trustor, the trustee, and the role of risk, Mayer et al. (1995, p. 712) define trust as "the willingness of a party to be vulnerable to the actions of another party based on the expectation that the other will perform a particular action important to the trustor, irrespective of the ability to monitor or control that other party"; Trust as socially-defined phenomenon - this definition of trust, which is viewed as a characteristic of the social fabric that facilitates interactions among parties, takes into account interpersonal behaviours, communication channels and interpersonal trust ties (Håkansson, 1982; Lewicki, McAllister and Bies, 1998; Tyler and Stanley, 2007).
} 
related to the elements of trust, social rapport provides a new dimension outside the scope of trust. The relationship marketing literature also suggests that 'offer-related' (i.e., competence, reliability, promptness) and 'person-related' (i.e., empathy, politeness) characteristics of the business adviser can affect the relationship as well as the establishment of trust (Grönroos, 1990).

Many of the characteristics of trust and the dimensions of relationship marketing are also core principles in the code of ethics for professional accountants (APES 110, 2008). The core principles include competence integrity, objectivity, independence and confidentiality. In addition to the previously discussed characteristics of competence and integrity, an SME will not seek advice from their external accountant unless they perceive their accountant's judgment is unbiased and without conflict of interest and that they can trust their external accountant to maintain confidentiality.

Where an accountant also provides statutory audit services to their client, there has been debate for many decades as to whether auditors should also provide non-audit services which would include business advice, though the debate is focused on public interest enterprises (i.e., listed public companies). Regulatory changes in the US (i.e., Sarbanes Oxley $(\mathrm{SOX}))$ have severely restricted the market for many professional services provided to listed audit clients. The impact is less prescriptive in other jurisdictions. For example in Australia the only legislative impediment faced by 'public interest entities' before simultaneously purchasing business advice from their auditors is the requirement for companies to disclose the services purchased (and the associated fee) as well as provision of statements by the auditor and the board that such services have not compromised auditor independence (Corporations Act 2001. 2004 CLERP 9 amendments).

In the SME environment there is no legislative restriction on the joint provision of statutory and non-statutory services. This is because in the SME environment firms experience greater alignment between owners and managers and thus less agency conflict than in large private and publicly listed firms. The professional guidance allows joint provision of services provided threats to the fundamental ethical principles are appropriately managed (IESBA 2006; APES 1110 2006; AUASB ASP 8, 1989). Responsibility for determining an acceptable threat to fundamental principles rests with the professional judgement of the external accountant. An SME will not seek advice from their external accountant unless they perceive their accountant to be independent. 
Prior empirical research provides little evidence concerning the intervening impact of trust, relationships and professional ethics play in enabling business advice exchanges between SME clients and external accountants. Gooderham et al. (2004), in a telephone survey of micro- and small businesses in Norway, find that the perceived competence of the external accountant to be the most significant predictor of reliance on the external accountant as business adviser. In contrast, Kirby and King $(1997,302)$ suggest the reason external accountants are not considered a source of management advice to small business " ... is not a matter of cost, rather one of perceived lack of knowledge/expertise of business demonstrated by the accountant". Based on results from a later survey of small businesses, Kirby et al. (1998) reiterate that "...small business owner managers believe that accountants lacked business awareness and were too remote from business" (p. $x$ ). Using tenure as a measure of the relationship, Gooderham et al. (2004) find no association between length of the SME's accountant tenure and reliance on their external accountant as a business adviser.

There is some evidence on the role of trust in the provision of banking services to SME clients (e.g., Zineldin, 1995; Turnbull and Moustakatos, 1996). Zineldin (1995) argues that trustworthiness dominates the banking sector precisely because of the potential high risks and uncertainties in the industry, while Knights, Noble, Vurdubakis, and Willmott (2001) maintain that trust is a necessary condition for the provision of services in the financial services industry. Meanwhile, Tyler and Stanley (2007) found that even though banks based their relationships on calculative and operational trust, SMEs were nonetheless more trusting of their banks compared with larger companies. This is because the SMEs approach to the bank-client relationship is primarily based on affective trust, while larger companies are more calculative in their approach. An important insight provided by Tyler and Stanley (2007) regarding trust is that bank clients assume bank personnel to be competent and that they are able to handle their information in the strictest of confidence.

2.3. Intervening Factors: Perceived Value of Services - A SME owner-manager is unlikely to purchase business advice from their external accountant unless they perceive the service provides value for money. Cameron (1995) investigated perceptions of the value derived from the external accountant's fee by 882 New Zealand 'small' businesses (Employing $<20$ staff). Traditional compliance services were regarded as cost-beneficial (value for money), but small business owners were neutral in their perception of the value of the cost of business advice. Kirby et al. (1998) and Cameron (1995) demonstrate that the issue of cost 
(affordability) is a major impediment to small businesses using their external accountant as a business adviser. Blackburn and Curran (1994) found the opportunity cost in terms of the time to seek suitable advice to be a deterrent. In a 2004 survey of 469 SMEs, Carey et al. (2005) found that accountants were perceived by their clients to be adding value to the firm. In particular, over $80 \%$ of SME respondents who purchase business advice are satisfied that they derive a financial benefit from such advice. We include perceived value of service as an intervening factor in the conceptual framework (see Figure 1).

\section{RESEARCH METHODS}

Data is collected through face-to-face interviews with key informants in Melbourne, Australia, and London, UK. These included face-to-face interviews with owner-managers, accountants and financial advisers. The interviews followed an interview protocol which provided scope for exploration of issues that emerged in the interview whilst at the same time covered a broad flow of topics that we sought to investigate (see Appendix A: Interview Protocol).

Table 1. Summary of Interviews UK and Australia

\begin{tabular}{|l|l|l|l|}
\hline & United Kingdom & Australia & Total Interviews \\
\hline Accountants & 4 & $7(5$ firms $)$ & 11 \\
\hline Financial advisers & 2 & 1 & 3 \\
\hline Small businesses & 3 & 4 & 7 \\
\hline Total & $\mathbf{9}$ & $\mathbf{1 2}$ & $\mathbf{2 1}$ \\
\hline
\end{tabular}

Of the 21 respondents, a spread of professional accountants, financial advisers and SME owner-managers were interviewed in Melbourne and London. Five accounting firms (seven respondent accountants) were from 2 nd tier accounting firms with international affiliation, two were medium sized accounting firms and two were small accounting firms. Of the three financial advisers, two were working in specialist financial advisory firms (one was from a small firm and one from a large sized firm), and one had recently been employed as a specialist adviser in a second tier accounting firm. These key informants were approached through their membership of professional organisations, including the ACCA in England and the CPA and CAs in Australia. All the interviews with SMEs were with the 
owner-manager, or a partner/shareholder of the organisation. These were selected through accountants on the criteria of independence and hence had autonomy over decisions within the enterprise. There was no deliberate attempt to 'triangulate' stories from accountants and their own clients because of potential breaches of confidentiality and ethical issues. Moreover, owner-managers and /or accountants may have been reluctant to disclose certain issues if the research design had linked specific firms to specific accountants. On the other hand, the business owners that were interviewed may, or may not, have used the accountants we also interviewed. The interview focused on their interaction with accountants and financial advisers in relation to their firm rather than their individual, personal matters. However, this distinction between 'business' specific and 'personal' specific advice becomes increasingly opaque when owner-managers require advice than spans individual and business issues. For example, this is often the case in family firms and in some micro firms when the income of the firms is indeed the income of the individual.

All the interviews were audio recorded and transcribed. Interviews lasted from 60 to 90 minutes and took place in the interviewees' offices between July 2008 and February 2009. In addition to conducting the interviews, the research team read through all the transcriptions to build up a thematic analysis of the way in which trust and its various components are influential in relations with SMEs and advisers.

\section{DESCRIPTIVE RESULTS}

\subsection{Sample Details and Descriptive Results}

The SMEs that participated in the study were from a selected range of industries (See Table 2). All the SME respondents were owner-managers, partners or shareholders. The final column in Table 2 shows the nature of business advisory services that SMEs purchased from their external accountant. Results suggest that while some firms relied heavily on their external accountant as an adviser (i.e., SMEAus02, SMEUK01, SMEUK02,SMEUK03) others purchased a more limited range of advisory services (i.e., SMEAus01, SMEAus03, SMEAus04).

The types of business advisory services in Table 2 can be further characterised as:

- Financial services, which can be classified into business advice covering issues such as cash flow and financial banking statements; and individual and family issues such 
as superannuation, asset structuring, income distribution and wealth accumulation strategy;

- Business operational services such as production efficiency, lease negotiation, payroll, HR or information technology (IT);

- Business dynamics such as on the purchase, transfer or sale of a business;

- Intangible services such as "being a sounding board" psychologist and friend;

- Family services, such as wills, estate planning, succession planning and mentoring.

Table 2. Summary of SMEs Interviewed

\begin{tabular}{|c|c|c|c|c|}
\hline Company & Sector, Industry & $\begin{array}{l}\text { Size: } \\
\text { Employees }\end{array}$ & $\begin{array}{l}\text { Business Advisory Services } \\
\text { Bought from External } \\
\text { Accountant }\end{array}$ & $\begin{array}{l}\text { Business } \\
\text { Advisory } \\
\text { Services, Other } \\
\text { Advisers }\end{array}$ \\
\hline SMEAus01 & $\begin{array}{l}\text { Wholesale/ } \\
\text { Importer consumer } \\
\text { products }\end{array}$ & 30 & None & $\begin{array}{l}\text { Financial } \\
\text { Planning } \\
\text { (Investments) } \\
\text { Mentoring, } \\
\text { coaching, } \\
\text { strategic } \\
\text { planning, } \\
\text { benchmarking, } \\
\text { Para-legal, human } \\
\text { resource support. }\end{array}$ \\
\hline SMEAus02 & $\begin{array}{l}\text { Manufacturing/Whol } \\
\text { esale/Exporting } \\
\text { Unique Australian } \\
\text { Clothing }\end{array}$ & 80 & $\begin{array}{l}\text { Acquisition and New } \\
\text { Business advice. Financial } \\
\text { Modelling } \\
\text { Assisting with Bank Finance }\end{array}$ & $\begin{array}{l}\text { Textile Industry } \\
\text { Consulting Group } \\
\text { HR, Marketing }\end{array}$ \\
\hline SMEAus03 & $\begin{array}{l}\text { Packaging Food and } \\
\text { Drugs }\end{array}$ & 50 & Business Structuring & $\begin{array}{l}\text { Task Orientated } \\
\text { Marketing, } \\
\text { Production }\end{array}$ \\
\hline SMEAus04 & $\begin{array}{l}\text { Retail and } \\
\text { Wholesale }\end{array}$ & 180 & Sale of Business & $\begin{array}{l}\text { Mentoring/Coach } \\
\text { HR }\end{array}$ \\
\hline SMEUK01 & $\begin{array}{l}\text { Personal Service - } \\
\text { Hairdressing }\end{array}$ & 20 & $\begin{array}{l}\text { Property and Finance } \\
\text { Advice } \\
\text { Milestone Events, payroll, } \\
\text { HR }\end{array}$ & \\
\hline SMEUK02 & $\begin{array}{l}\text { Retail and } \\
\text { Wholesale, } \\
\text { Manufacturing } \\
\text { Service - Bespoke } \\
\text { Clothing Sampling }\end{array}$ & 7 & Structuring, HR & $\begin{array}{l}\text { Regional } \\
\text { Business Centre - } \\
\text { Various }\end{array}$ \\
\hline SMEUK03 & $\begin{array}{l}\text { Service B-To-B - } \\
\text { Design \& Marketing }\end{array}$ & 5 & $\begin{array}{l}\text { Financial Advice, General } \\
\text { Business Advice }\end{array}$ & \\
\hline
\end{tabular}


Tables 3 and 4 summarise the type of business advisory services provided by accountants and where possible the contribution of this activity to total fee income. The 11 professional accountants interviewed worked at nine accountancy firms. The three professional financial advisers worked at two unrelated financial advisory firms and one worked in a second tier accounting firm. Five of the nine accounting firms were classified as 2nd tier with international affiliation; two were medium sized firms, while two accountants were from small accounting firms. Of the financial advisers, one was from a small firm, one from a medium sized firm, and one from a large firm.

Table 3. Summary of Accountants Interviewed: Provision of Services to SMEs

\begin{tabular}{|c|c|c|c|c|}
\hline $\begin{array}{l}\text { Accountant } \\
\text { Interviewed }\end{array}$ & $\begin{array}{l}\text { Size of } \\
\text { Accountancy } \\
\text { Firm }\end{array}$ & Interviewees & $\begin{array}{l}\text { Types of } \\
\text { Business } \\
\text { Advisory } \\
\text { Services } \\
\text { Provided by } \\
\text { Firm }\end{array}$ & $\begin{array}{l}\text { Proportion of Firm } \\
\text { Revenue } \\
\text { Contributed by } \\
\text { Business Advisory } \\
\text { Services }\end{array}$ \\
\hline AAus01 & $2^{\text {nd }}$ Tier & $\begin{array}{l}\text { Partner -SME } \\
\text { Accounting } \\
\text { Services }\end{array}$ & $\begin{array}{l}\text { Financial } \\
\text { Management } \\
\text { Services. } \\
\text { Planning, } \\
\text { Forecasting, } \\
\text { Succession } \\
\text { planning, } \\
\text { Superannuation, } \\
\text { Asset Protection }\end{array}$ & $40 \%$ \\
\hline AAus02 & $2^{\text {nd }}$ Tier & $\begin{array}{l}\text { Partner -SME } \\
\text { Private } \\
\text { Clients }\end{array}$ & $\begin{array}{l}\text { Banking, Wealth } \\
\text { Creation, } \\
\text { Succession } \\
\text { Planning }\end{array}$ & $40 \%$ \\
\hline AAus03 & $2^{\text {nd }}$ Tier & $\begin{array}{l}\text { Partner -SME } \\
\text { Audit }\end{array}$ & $\begin{array}{l}\text { Financial } \\
\text { Statements, } \\
\text { Valuation, } \\
\text { Business Sale } \\
\text { and Purchase, } \\
\text { Due Diligence }\end{array}$ & $20 \%$ \\
\hline AAus04 & $2^{\text {nd }}$ Tier & $\begin{array}{l}\text { Partner -SME } \\
\text { Private } \\
\text { Clients }\end{array}$ & $\begin{array}{l}\text { Corporate } \\
\text { Advisory, } \\
\text { Private Wealth } \\
\text { Advisory, } \\
\text { Investment } \\
\text { Strategy, } \\
\text { Succession } \\
\text { planning, } \\
\text { Business Sale } \\
\text { and Purchase }\end{array}$ & $60 \%$ \\
\hline
\end{tabular}




\begin{tabular}{|c|c|c|c|c|}
\hline & & & $\begin{array}{l}\text { Forensic } \\
\text { Accounting }\end{array}$ & \\
\hline AAus05 & $2^{\text {nd }}$ Tier & $\begin{array}{l}\text { Partner -SME } \\
\text { Private } \\
\text { Clients }\end{array}$ & $\begin{array}{l}\text { Structuring, } \\
\text { Superannuation, } \\
\text { IT, HR, Finance } \\
\text { Brokering, } \\
\text { Providing } \\
\text { Networking }\end{array}$ & $25 \%$ \\
\hline AAus06 & $2^{\text {nd }}$ Tier & $\begin{array}{l}\text { Partner -SME } \\
\text { Private } \\
\text { Clients }\end{array}$ & $\begin{array}{l}\text { Purchase And } \\
\text { Sale of } \\
\text { Business, } \\
\text { Structuring, } \\
\text { Financial } \\
\text { Management, } \\
\text { Wealth } \\
\text { Management, } \\
\text { Superannuation, } \\
\text { Banking }\end{array}$ & $25 \%$ \\
\hline AAus07 & Small & Partner & $\begin{array}{l}\text { Financial } \\
\text { Planning, } \\
\text { Mortgage } \\
\text { Broking, } \\
\text { Superannuation, } \\
\text { Business } \\
\text { Strategy, } \\
\text { General } \\
\text { Business Advice }\end{array}$ & $50 \%$ \\
\hline AUK04 & Medium & $\begin{array}{l}\text { Partner } \\
\text { Financial } \\
\text { Adviser (Part } \\
\text { of } \\
\text { Accountancy } \\
\text { Firm) }\end{array}$ & $\begin{array}{l}\text { Financial } \\
\text { Planning, } \\
\text { Retirement } \\
\text { Planning, } \\
\text { Pensions, } \\
\text { Protection }\end{array}$ & $100 \%$ \\
\hline AUK01 & $2^{\text {nd }}$ Tier & $\begin{array}{l}\text { Partner -SME } \\
\text { Clients }\end{array}$ & $\begin{array}{l}\text { Business } \\
\text { Purchase and } \\
\text { Sale, HR, } \\
\text { Financial } \\
\text { Management, } \\
\text { Company } \\
\text { Secretarial } \\
\end{array}$ & $\mathrm{n} / \mathrm{a}$ \\
\hline AUK02 & Medium & $\begin{array}{l}\text { Partner -SME } \\
\text { Client } \\
\text { Services }\end{array}$ & $\begin{array}{l}\text { Company } \\
\text { Secretarial, HR, } \\
\text { Business } \\
\text { Purchase and } \\
\text { Sale }\end{array}$ & $50 \%$ \\
\hline AUK03 & Medium & Partner & $\begin{array}{l}\text { Financial } \\
\text { planning, } \\
\text { retirement } \\
\text { planning }\end{array}$ & $100 \%$ \\
\hline
\end{tabular}


While accountants and SMEs alike often found it difficult to precisely distinguish business advice from statutory, compliance services, the overwhelming majority acknowledged that business advice was an emerging and important segment of the service market. Business advice extends from matters directly relevant to the SME business, to the external accountant acting as trusted confidante and adviser on private and family matters.

Table 4. Summary of Financial Advisers Interviewed: Provision of Services to SMEs

\begin{tabular}{|c|c|c|c|c|}
\hline & $\begin{array}{l}\text { Financial } \\
\text { Adviser Firm } \\
\text { Size }\end{array}$ & Interviewees & $\begin{array}{l}\text { Types of } \\
\text { Business } \\
\text { Advisory } \\
\text { Services } \\
\text { Provided by } \\
\text { Firm }\end{array}$ & $\begin{array}{l}\text { Proportion of Firm } \\
\text { Revenue } \\
\text { Contributed by } \\
\text { Business Advisory } \\
\text { Services }\end{array}$ \\
\hline FAUK01 & Large & $\begin{array}{l}\text { Partner } \\
\text { Financial } \\
\text { Adviser }\end{array}$ & $\begin{array}{l}\text { Financial } \\
\text { Planning, } \\
\text { Investments, } \\
\text { Mortgages, } \\
\text { Pensions, } \\
\text { Protection }\end{array}$ & $90 \%$ \\
\hline FAUK02 & Small & $\begin{array}{l}\text { Partner } \\
\text { Financial } \\
\text { Adviser }\end{array}$ & $\begin{array}{l}\text { Investments, } \\
\text { Pensions, } \\
\text { Mortgages, } \\
\text { Protection }\end{array}$ & $100 \%$ \\
\hline FAAus01 & Medium & $\begin{array}{l}\text { Partner -SME } \\
\text { Services } \\
\text { Financial } \\
\text { Adviser }\end{array}$ & $\begin{array}{l}\text { Business Sale } \\
\text { and Purchase, } \\
\text { Wealth } \\
\text { Management, } \\
\text { Structuring, } \\
\text { Superannuation, } \\
\text { IT, Estate } \\
\text { Planning }\end{array}$ & $60 \%$ \\
\hline
\end{tabular}

Although interviews with financial advisers were an initial integral part of the research design because of the nexus between individual needs and business needs found in earlier research (Carey and Tanewski, 2005). However, as the research progressed it became increasingly apparent that financial advice was provided by accountants and financial planning has become part of the overall portfolio of advice that they provide. The validity of this indicative finding, that is that financial advisers are focused on the individual rather than the business, may be worth testing in a larger scale empirical research survey. 


\section{UNDERSTANDING THE DEMAND AND SUPPLY OF SERVICES}

\subsection{The context of the SME and importance of the owner-manager}

In order to understand the demand drivers for an SME to purchase services from an external accountant we first need to understand what is a SME. Our results found that for many owner-managers running a business is not just about 'doing the business': it is also closely aligned to the personal motivations and life matters of the SME owner. With this comes personal objectives and family activities, which involve matters and decisions that are deeply considered and effect more than just business operations. Such findings are not unusual, and are especially the case with micro enterprises.

The SME owner is often a sole proprietor, or sole decision maker and needs a trusted adviser who is empathetic to the needs, desires and dynamics of their particular business and family. As one SME respondent said: "I trust him [the accountant] implicitly with my intimate details of my thoughts about where the business is going and where the family is going" (SMEAus01). Another explained that the firm had developed successfully using the same accountant: "Well I just think it's a 30 year relationship where we totally trust what they do and we've always been satisfied with the standard of the service.../... we don't question it. ... Yeah, I'm not questioning that at all because in many ways it's probably the best way to go, isn't it? But it's almost irrational in some ways in the sense of the way we buy everything in today's society. Shop around with the internet and all that. But I mean with this sort of service it's more complex isn't it" (SMEUK01)

This analysis was reinforced by several of the accountant respondents. One accountant said: "When we talk about 'the SME market', we are talking family businesses and to provide effective advice you need to understand the family first" (AAus02). The respondent accountant continued to say: "The SMEs are about the life of an individual, a couple or $2 / 3$ partners, it's not a clinical business and it's not about the delivery of clinical services and that's why we need trust" (AAus02). Another accountant's response chimed with this perspective: "The business of the SME is so deeply embedded in that individual's personal wealth ..., that it is critical the adviser understands the SME requirements and delivers to those requirements" (AAus04). A UK accountant pointed out that this was not merely confined to micro-firms: “...We give a very personal service and we are very accessible and we do care about our clients and that, I think, comes through within a 
relationship and if people feel that and that all comes back to trust. They consider that we are on their side and we will do our best within our professional boundaries" (AUK01)

In short, another way to describe voluntary advisory or non-compliance services provided by an external accountant to their SME clients is business and personal intrinsic services. These services are essential to the well being of the individual, the business and the family.

\subsection{Sources of Demand for Advice}

5.2.1. SME business environment dynamics - Environmental turbulence, in the form of market and/ or regulatory change, is an important stimulant for the owner-manager to seek external advice. Most SME environments tend to be dynamic with businesses facing constant turbulence caused by legislative reform, competitor improvements, broader economic conditions (such as a recession or boom), public policy changes (such as a change in fiscal policy) and the respective and individual thoughts and actions of the SME owner(s).

This dynamic environment gives rise to demand for business services, such as advice on the purchasing or selling of a business, effectively structuring a business or personal wealth holdings and distributions. The interviews with accountants and SMEs underlined this commonly held view. One accountant explained "... demand depends on the phase of the business, maybe a lot of advice early, then when buying or selling a business" (AAus06). Another accountant emphasised that "... problematic economic times can drive demand or one-off events such as divorce, a more competitive industry or a highly geared business" (AAus04). All firms will face succession or business transfer issues and often the accountant is the first port-of-call by owner-managers for advice: "They might just want to talk about the succession of the business for instance. I mean that's quite a big issue. We've got an ageing population with sole traders and partnerships. They need to get their firm fit totally to carry on after they retire, so those are issues. Inheritance tax I want to give this property to my son but I don't like his wife. I think they might divorce. How can I do this without her getting involved [ ]. All sorts of issues. It's... a lot of it's very personal to their business and that's why you need this relationship trust because it's that knowledge of their business and their life." (AUK01).

Such episodes could be termed 'milestone' events and may prompt the SME owner to seek out the services of the external accountant, having already built a continuous 
relationship of trust. Most small firms do not have sufficient in-house resources, certainly to deal with 'one-off' events such as a rapid growth spurt or on the other hand, business exit and this means that they would tend to look to their external accountant to fill the gap in their experience and knowledge base. In such situations, accountants could be regarded as an external resource.

'Less experienced SMEs and those SMEs with multiple owners appeared to be more likely to seek external business advice. Furthermore bank debt requirements drive demand for external accounting services in the form of cash flow and quarterly statements.

\subsubsection{The importance of perceived added value of business services - The fieldwork} demonstrated a fundamental difference between owner-managers motivations to seek noncompliance business services and compliance services. A key element that determines if an SME purchases non-compliant, business advice is whether they perceive that the advice adds value to their business. In contrast, compliance work was generally seen by owner-managers as a necessary cost to the SME business, but one which added little, if any, value to the business. As one owner-manager said about his compliance accountant “...he's your compliance keeper and you certainly rely on somebody to make sure you're doing what you have to do" (SMEAus04). Similarly, one UK owner-manager implied that, other than in the provision of advice at key points, the accountant's services were a cost to the business: "...the way I see it, the accountant doesn't make me money really. Well, this last month he didn't anyway. He was making money, not me. So, you know, if I've got any queries... For instance, we did a bit of international trade, which is an area that I don't really know about. Like "How do you deal with that?" and that's sort of asking the accountant questions sort of thing. He did help me with the initial set-up of how to run a limited company. That's where I learned how to do it - from the accountant" (SMEUK02). Another owner-manager put his view more succinctly: "I don't read the accounts. I just accept what we're charged and think well it's got to be done" (SMEUK01).

The view that compliance services were a cost rather than benefit to the business was reinforced by most accountants who agreed that the compliance services provided no value to the SME business. As one accountant said "...the value they get from compliance is nil, but they get immense value from just being able to pick up the phone and talk to someone who knows their affairs back to front and give them an answer on the spot" (FAAus01). In explaining this different owner-manager perspective, one accountant speculated: “Our 
[compliance] work tends to be repeat work so that's an overhead. The specialist advice when you want something specific - if it's what they want then they'll pay for it" (AUK01).

In contrast to the perception of the value of compliance services, business advice services provided a more positive story. Business advice services were regarded as adding value to the business because it is what the SME demands rather than a derived demand to meet statutory requirements. A number of factors influenced its take-up. One owner-manager emphasised that as long as the 'price was right', then [business] advice was important: "I think the cost of it doesn't really come into it, not at the very beginning I don't think. You know, it just doesn't because, let's face it, if someone gives you very good advice and it's someone you really trust ... /..., it's worth paying for the advice. But saying that, if it was a ridiculous price, then no" (SMEUK03). Before buying advice, one SME indicated that the following trade-off is necessary: "Are there benefits that go with the service and how much does it cost?" (SMEAus03). This view was reinforced by accountants and one said “...there is more pressure from the client base to get more value added" (AAus03).

\subsection{Owner-manager influence on advice seeking}

The extent to which external business advice was sought and purchased was found to be influenced by the owner-manager. As one accountant respondent said: "The driver of demand is driven by the personality of the SME owner being either 1) self directed people, or 2) people who seek advice to assist them make decisions" (AAus04). In some cases, advice seeking was an iterative process whereby owner-managers heard of a service from a source other than their accountant and this stimulated them into action.

We term the first group "self directed individuals". These owner-managers are more confident to rely solely on their own judgements and therefore, less likely to buy advice believing they adequately possess the necessary business expertise. These individuals were also more likely to buy business advice following a 'milestone event' which could be externally or internally generated. Typically, these events could include changes in regulation, a fundamental shift in the business cycle, retirement or succession, or changing family circumstances. The second group of owner managers were individuals who liked to validate decisions by seeking confirmatory advice. This "validator" group took more time to develop their confidence in a decision path and thus tended to make more considered 
decisions. This group were also more likely to seek on-going advice rather than seek it in response to an imposed change or event.

These two SME types are illustrated by the following contrasting attitudes represented by SME respondents. One SME said: “... accountants did offer other services but I didn’t want them" (SMEAus04). Similarly, another owner-manager indicated that '... because it's a huge [accountancy] company they've got lots of different departments .../... They've got a marketing department, they've got this department, got that department and because you're part of this company you could access these - obviously at a cost. But, you know, as I say, it's early days yet" (SMEUK02). On the other hand, validators are illustrated by owner-managers stating that "You've got to not let your ego get in the way ... some successful people are very autocratic, but I'm not that sought of person ...you can become blinkered and convince yourself that you're right about things when actually you don't have the knowledge base to make decisions" (SMEAus01). Even when an accountant is not actually the appropriate source of advice, validators may request their advice; "I feel we can say something to him which I wouldn't want to say if you'd come along as a financial advisor. It's not quite the same. He's not a financial advisor, but I would trust him to ask, you know, like "What do you think we should be doing on this?" and if he said "That's really out of my sphere, but I would do this," he would probably recommend someone to us" (SMEUK03).

As one accountant said: "The SME client is very driven, they know it all, a lot of them are still mainly one owner, they have created the business, it is hard for them to let go" (AAus01). Providing further insight into the group categorised as "validators", another accountant said that those SME owners that are a bit unsure of themselves were more likely to seek his advice (AAus07).Following an analysis of the transcripts, we classify four of the seven SMEs as 'self directed' and three of the seven SMEs as 'validators' (Companies SMEAus01; SMEAus03; and SMEUK03).

\subsection{Existing SME - accountant relationships as a basis for non-compliance business advice}

As expected, the fieldwork showed that accountants with an already established relationship with SME owner-managers were in a strong position to provide further business advice to these firms. However, this was not guaranteed and it was important that trust had been developed between the owner-manager and the accountant. Trust was developed through a 
combination of supplying compliance services to SMEs and demonstrating competence and professionalism in this process. In some cases, owner-managers relied on a recommendation from their accountant to a supplier of non-compliance business advice, if the requirement was outside the expertise of the accountancy practice.

\subsubsection{Accountants rely on referrals rather than perform pro-active marketing - One of} the important questions in the study was the extent to which accountants exploited the relationship with their SME clients in order to supply non-compliance services. The results suggested that most accountants are passive rather than active marketers of their noncompliance services. As one respondent accountant stated: “...demand for my services is largely referral based, from a partner within the firm or a key contact from within the SME network”(AAus04). Another accountant respondent said: “... almost categorically business advisory services are a spin off from the compliance services" (AAus02A referral provides the SME owner-manager with some initial assurance that the accountant is sufficiently competent. Even with the advent of internet technology, personal referrals were a dominant form of new businesses: "We're not really good at marketing. Our business has grown to what it is, I mean we now have nearly 40 people but it's not because we're particularly good at marketing. It's how we [operate ]. Look at our website. It's pretty much non-existent" (AUK02). The reliance on recommendation did not mean a steady-state business and could facilitate growth, as explained by one accountant: “..we currently get something like 70 clients, [new] clients a year and we probably lose 3 or 4 clients a year so we are a growing practise but we're not expanding exponentially. Just gradual progressive growth and we don't market to any degree because we've got this flow of clients coming in from recommendation" (AUK01).

This is not to deny the role of the internet as a marketing and information source. Our findings suggest that websites, were occasionally used by owner-managers as a supplement to a recommendation. On the other hand, accountants themselves often researched potential clients through the internet: ".. 99\% of all clients come through recommendation and that's very important. I always say to clients 'If you're happy, recommend.' .../... You know, I've had a couple of telephone calls with them [the recommended firm]. 'What sort of things do you [provide]...? I've learned about the business through the Internet and I've got information from the previous accountant' (AUK03).

\subsubsection{The marketing of services through networks - A common technique used by} accountants to communicating their broader expertise to clients was through the use of networks or forums for SME owner-managers. The majority of accountants interviewed 
indicated that it was through these networks that SMEs became familiar with the other services that an external account might provide their business.

In some cases, these additional services were provided within a context of wider environmental changes. Many SME owner-managers do not have the time to scan the environment beyond the immediate confines of their business. As such, the role of membership organisations, such as chambers of commerce and trade, and professional bodies, were often instrumental in brokering communication. For example, where there are government changes to legislation such as FBT, GST, VAT, Superannuation Guarantee, Superannuation Contributions, and Self Managed Superannuation Funds, many accountants indicated that they responded to these changes by creating forums and information meetings to inform their clients of the changes and in turn displayed their competency which may lead to further work. As one respondent accountant said: "We run seminars to show we can supply [other discretionary services]". The same accountant went on to say "we respond to a need like government change by holding forums" (AAus06). Accountants were invariably members of local chambers of commerce or relevant professional and sector business groups which acted as a vehicle for both the dissemination of their services and the ability to glean new information regarding their market. One accountant, for example, made their presence known in the local newspaper: "I mean we rarely advertise. I .../... do an article for my local paper once a month. But that doesn't make my practice [explicitly] because I do that for [an accounting professional body] so I'm used to being the spokesperson so it's my name and my picture so there's a recognition there. You have contacts with local solicitors and bank managers..." (AUK01).

\subsubsection{SMEs mixed views on the value worth of accountants in providing discretionary}

services - We found that all of the SME owners used a number of advisers and despite having an existing relationship with their accountant for compliance services, not all SMEs used an external accountant for other business services. A number of reasons were provided for this outcome. The market for business advice is highly competitive and while external accountants are well placed to also gain this work, they need to convince clients they have the necessary business expertise to solve the owner-manager's issues.

Whilst all SME owners understood and agreed the necessity to have a competent and trustworthy external accountant for compliance services, most SME owners utilised other 
professional service providers for discretionary services instead of, or in addition to, their external accountant.

A number of owner-managers regarded the use of accountants for accountancy matters but instead of extending their relationship, preferred to use other sources for other issues. For example, one SME respondent used an external accountant for compliance services, a financial planner for wealth management services and an independent business adviser for business advisory services (SMEAus01). The owner-manager stated he used the business adviser for mentoring, consulting, coaching, business development, strategic planning and paralegal services. The owner also believed that not one person has all the required knowledge to operate successfully and uses the business adviser to benchmark himself against other business owners. The owner indicated that as his business became more complex, the depth, complexity and the variety of advice required increases.

Having credibility in the industry was cited by some owner-managers as significant in the advice seeking decision making process, although for a few this was regarded as crucial. One owner-manager uses a business adviser who was once a successful business owner, and is someone who provides mentoring and coaching services, is seen as a good sounding board and “...someone I can tell stuff you couldn't tell staff or the management team" (SMEAus04). This SME owner argued that many accountants were 'out of touch' with his particular industry and had not received value for money on past discretionary services provided by an external accountant. Notwithstanding that experience, the SME owner had recently sold a business and experienced excellent service from the external accountant saying "...the accountant really stood up from the sale transaction viewpoint and showed me their worth" (SMEAus04). The need for accountants to be more of a sounding board for a range of issues - a general practitioner for the SME - was in the consciousness of some accountants: "If they've got a problem we talk it through.../... They may not want specific advice because they haven't got anybody.. I mean it can be a sole trader or a partnership person in that partnership. And they've got a problem and they have got nobody on their side. They can't talk to the bank because the problem might be the bank. So we are somebody who's on their side and often that's the case if they are folding up.../... they just want to use you as a sounding board or an option for us to say well have you thought of this? (AUK01).

The reticence to extend the advice function of their accountant displayed by a minority of owner-managers appeared to be based on a notion that specialisation required a 
division of labour between different advisers in the network. This was exemplified in a response by one owner-manager who said: "I don't use accountants for business advice and for marketing and production. I go to people who are most involved in those fields" (SMEAus03). That SME owner said: "I don't think the accountant is that critical in the business" (SMEAus03).

From the supply perspective, a number of accountants interviewed suggested the need for increased specialisation within their particular fields of expertise. Where possible, accountants were keen to provide an appropriate level of expertise, especially if the business was considered to be of a sufficient scale. In some instances, this led to the establishment of a dedicated account manager who utilises the expert services within the firm to satisfy the client SME demands. As one respondent accountant said: "SME's come to mid-sized accountants to get expertise in a certain issue and advice across broad issues" (FAAus01). The accountant continued to say that "we have one single contact point, but then use the broad skills of the firm". Another accountant said: "we say to our clients, we're your one stop shop. Our clients come to us if they need any recommendations to anything else and even very specialist work that we don't carry out we will go and find it”(AUK01).

For smaller accounting practices, specialisation of non-compliant business services led to the accountant referring their client to other members of their network although they were the first port of call. For example, one small firm required a solicitor: 'I feel we can say something to him which I wouldn't want to say if you'd come along as a financial advisor. It's not quite the same. He's not a financial advisor, but I would trust him to ask, you know, like 'What do you think we should be doing on this?' and if he said 'That's really out of my sphere, but I would do this,' he would probably recommend someone to us. One time we needed a solicitor for something. There was some money that was owed to the company .../...and he said "I know someone who can help you do that." (SMEUK03).

The preceding analysis suggests that an expectation gap has opened up between what the SME owner needs and what the external accountant is able to supply. As one SME said "They [the accountant] could be more specialised in certain areas that can truly offer advice rather than trying to be a jack of all trades" (SMEAus04). Whilst small accountancy practices appeared to gain an advantage in terms of empathy with small firms, some of our interviewees were prepared to question the capacity of their accountant to provide business 
advice, no-matter how close the relationship: "I suppose it might be if a few things happened and I thought, hang on, he's not coping. Maybe he's got too much on" (SMEUK03).

This suggests even smaller accounting practices might further embrace a variation in the model adopted by larger international accounting firms with their focus on industry specialization and draw upon a network of approved advice suppliers. This may involve nurturing a multi-disciplinary network of suppliers, organised around industry expertise. Although this may mean that the smaller accountancy practices do not try to provide a comprehensive service in-house, their role in the referral hub would be significant.

Indeed, most accountants interviewed recognised the importance of developing specialist business expertise or creating a structure which provided easy access to such expertise. To illustrate this point, one accountant said "...accountants are a distribution network" (AAus05), implying that if they did not possess the specialisation required, they would find that specialisation for the client SME. For the larger accountants interviewed, this sometimes meant referring SME clients to others within their business “...new standards require more specialisation, so we give more work to other partners who specialise in a particular area" (AAus03). A further strategy was to recognise that the accountancy practice specialises in specific sectors: "It's actually going for niches because it allows you [to bat much higher]. If you were just a firm that takes on everything, you're not batting higher..../... So some of our biggest niche markets are TV, media and barristers.” (SMEUK03).

Perhaps the accountants have not sold or communicated their ability to provide discretionary services comprehensively sufficiently to their clients and this is a matter for further discussion within this paper.

\subsection{SMEs and their accountants - the process of developing trust}

The interviews with SME owner managers explored the role of trust explicitly. Although we heard a number of stories regarding the development of the SME-accountant relationship from both parties, a general pattern emerged. It was clear that trust is built through an ongoing relationship between the accountant and the SME client, and is developed over time. The initial basis for trust to develop is a display of competence by the accountant. This is usually demonstrated in the provision of statutory services. With time and through a series of 
interactions with the SME, external accountants are then able to demonstrate empathy with their clients. A relationship forms over time and is then reinforced with social rapport.

There was consensus among SMEs interviewed that accountants are one of their trusted advisers. This was emphasised by one accountant in discussing this in relation to their clients: “They've got to trust. They've got to believe... I'd say it's no different than them going to see a doctor. You know, if they're going to see a doctor and they go to see two or three people, they've got to think they're going to get the best.../...that's why I said that recommendation is so important. Because if you need a doctor, the best way you're going to go to that doctor is to say 'Well, you know, Mr Smith had the same problem I've got and that's why I'm going to go and see him.' (AUK03)

However, before an owner-manager of an SME can rely on their external accountant for business advice, it was critical the accountant possess and displayed qualities such as competence, empathy, honesty, integrity, and had a good social rapport. These are the elements in the relationship which build trust.

One accountant said: "... our business is about building relationships ..." and "... it's the ability of the client to be able to contact you and for you to answer their questions in an intelligent manner [competence] and honestly. If I can't answer the question, I get one of our specialist partners to answer it and I communicate and manage the answer [empathy]" (AAus03).

5.5.1. Trust develops over time - The relationship between the SME client and the external accountant are built over time. In some instances the SME may not purchase other nonstatutory (business advisory) services from their external accountant for 1-5 years from initial contact or discussion. As one accountant said: "We start from an ethical and trusting base: the client relationship builds over time" (AAus06). One SME underlined the significance of time in the development of trust: "Well I just think it's a 30 year relationship where we totally trust what they do and we've always been satisfied with the standard of the service" (SMEUK02).

5.5.2. The role of social rapport - Whilst competence was an essential element for the development of trust, social rapport also emerged as a significant factor in helping build a base for the accountant to sell other services and for the SME. As one accountant said: “Social rapport plays a big part in building trust, you don't need to socialise outside of work 
but just going to see them a couple of times a year" (AAus03). Another accountant said: “... the people whose persona is more identifiable with my own will go beyond the compliance work and purchase other services" (AAus05). For one accountant, social rapport was considered 'essential' for the development of the relationship with specialist clients: "Once you get known in the industry.../... people walk in wanting to come to you because you've found out about their industry as well. 'What are the trends? What is happening? What's happening at the Revenue? What's happening in the courts?" (AUK03).

One owner managers' views on the role of social rapport tended not to mirror those of accountants since they emphasised much more the 'business' side of the relationship. This is not entirely surprising since they are not the people who are seeking to market services. One owner-manager stated "social rapport is important for building that partnership, [and] being part of the team" (SMEAus01). The owner-manager added: “...it's less [of] a personal relationship: the primary thing has always been the business side for both of us" (SMEAus01). Another owner manager was less committed regarding the development of a social rapport: “... you can’t have a business relationship with a friend” (SMEAus04). However, owner-managers and accountants displayed a 'managed' social relationship and this tended not to spill over into socialising: "I mean there might be something the bank had invited us to. [The accountant] might be there in his capacity as an accountant so no, we don't socialise in that way but after 30 years we do have a good relationship. If I bump into .../... on the street we shake hands and say how have you been, how's things going for you, what's happenin ,.../... that type of thing. But no, I would say it's $90 \%$ a professional relationship" (SMEUK03).

None of the SMEs indicated that their relationship with their external accountant had become a regular social relationship outside of the context of a working relationship. However, two accountants indicated they socialised with clients outside the working relationship (Accountant AAus02 and AAus07). Interestingly one accountant said "social rapport is critical" and that "... business services, that's where the value add lies, but you can't do that unless you're mates, how could you? You don't understand it otherwise" (AAus02). This was not, however, a common approach.

The majority of accountants suggested that although they are surrounded by the trappings of an institutional environment (and therefore 'institutional trust': Bennett and Robson, 1999), it is the individual who builds the relationship and cements that relationship 
for the firm. One accountant stated that the "individual is building the relationship, not the firm" (AAus03), while another accountant said "our firm is trying to make it about the organisation but the truth is it's about the individual relationships" (AAus02). Even when the accountant had to relinquish being the single point of contact in the relationship with the SME, the language they used implied the retention of some control in the relationship: "I provide one point of contact and then I use the broader skills of the firm" (FAAus01).

The interviews, therefore, provided mixed views regarding the significance of social rapport in the development of the SME-accountant relationship. It appeared that an element of social rapport was required as a minimum to allow a relationship to flourish, although it was not essential that this had depth other than for business purposes. For the accountant in particular, working on the relationship was important.

\subsubsection{The roles of competency and expected levels of competency in the SME-} accountant relationship - Accountants are relatively well educated and are put through a rigorous professional examination and testing regime to enable them to practice as accountants. This gives rise to their fundamental qualities of competency and assumptions by both accountants and owner-manager clients that they will be exercise this competency by following industry standards.

The majority of accountants' work derives from referrals, either from within the firm or from within the SME owners network. Underlying the referral system, one accountant provided the following explanation: "Referrals imply you are competent" (AAus05). SME respondents confirmed this view, as one SME said “...competency is a given” and “...it's only important I get advice that works" (SMEAus03). This was reinforced by another ownermanager who argued: "I need competent advice. They've got to be competent". Thus, the fieldwork suggested that by working in a profession, accountants benefitted from an assumed level of competency by owner-managers. This finding is similar to Bennett and Robson (1999) in their classification of accountants as having institutional trust. Our results demonstrate that this basic level of competency is fundamental to a continuing relationship that has been built on through social rapport over time and individual trust.

This notion of possessing an assumed level of competency because of the standards associated with the accountancy profession was echoed amongst accountants themselves. As one accountant pointed out: "I am a chartered accountant. People accept that I have a level of 
knowledge and therefore it comes down to the relationship". He continued to explain that "if you're not competent then you will never form the trust and the long standing relationships" (AAus06).

All respondents agreed the core competency of the external accountant is around compliance tasks. But not all accountants have developed broader business expertise to the same extent. For some accountants, compliance work continued to represent the core business whilst for others non-compliance work was more important (see Table 3) and of growing importance. Interestingly, one accountant (AUK01) indicated that they had focussed exclusively on growing their business advice competency and at the same time outsourced the compliance work within the firm to India. The former was considered to necessitate greater levels of business acumen and expertise, whilst the latter was considered more routine. This differentiation was reflected in the income stream for the accountant.

The above findings suggest that whilst accountants were assumed to be competent in terms of the provision of compliance advice, since after all this is what they have been formally trained and examined in, they had to 'earn' levels of competency by owner managers. The accountants interviewed demonstrated a variety of techniques for communicating their competence in their provision of business advice. Some emphasised hard work and dedication around compliance services. As one accountant said: “... my hard work and competence has created trust" (AAus03). Other accountants with more engaging personalities are more likely to directly market their broader business expertise to their clients.

5.5.4. The role of empathy in the accountant-SME relationship - Empathy involves understanding and genuinely caring about the clients' interests. The fieldwork found that empathy was identified by all accountants and owner managers as a critical ingredient to a successful client relationship and the provision of business advisory services. For some accountants, empathy was almost an ethical issue and they had to demonstrate this in dealings with clients. As one accountant said "we have an obligation morally and ethically to represent their best interests" (AAus04).

The means of demonstrating empathy was not easy. One accountant said "... the key ingredients of caring about your client are taking the time and trouble to understand his business. I visit my clients at their business, and it breaks down the tension" (AAus05). 
Turning to the owner-manager perspective, one SME emphasised the role of empathy in their statement "I need someone who understands small business and understands the pressures and workloads of the person that runs the company" (SMEAus02). Another ownermanager said "You [the accountant] have to act as if you are a department of our business" (SMEAus01).

Empathy is important to the SME owner in their external relations but it is not the exclusive domain of external accountants. SME owners said that it was also important that their non-accountant, business advisers also displayed empathy. For example, one ownermanager stated that their adviser had a "... genuine understanding of our business and who we are, [and] our objectives" (SMEAus01)

5.5.5. The role of trust - Trust includes professional or institutional trust, the trust in the firm and the trust in the individual. Society awards accountants institutional trust.

SME's require the services of accountants to help them comply with government regulation such as taxation. If the SME does not comply they may face punitive penalties and in some cases jail sentences. It is because of both the institutional setting and the provision of compliance services that accountants derive their trusted adviser status and facilitate the link between business and government. Arguably the accountants play a filtering role making sure the system functions legally. Honesty is one of the most valued qualities in society; if someone is honest they are by implication trustworthy. The external accountant's primary compliance role requires them to be honest and honesty leads to trust.

Accountants are conservative in the manner they attend to their work, either in gathering and providing advice to clients or complying with government legislation and requirements. Should accountants break the law or recommend clients break the law they may face financial penalty, loss or reputation or even being barred from practicing and hence loose a livelihood which is well paid and valued in society.

An important role of the external accountant is to ensure their clients are in compliance with the law and SME clients indicated that an important role of the accountant is to keep them honest. It is this very relationship of "required honesty" that gives prominence to the trustworthiness of the accountant/client relationship. 
The primary evidence highlighted the significance of trust as a linchpin in the SMEaccountant relationship. There was a consensus that external accountants are trustworthy and that trust is critical to relational exchange. As one accountant said "...why do people come to accountants?..Because they trust you, they begin to understand that you form part of their success story, but trust is an outcome not a driver"(AAus05).

Trust, however, is not a given. Accountants need to work hard to obtain the trust of the SME. As one accountant said "initially it's to do with personality and the relationship, then trust follows" (AAus06). Another accountant said "Trust is critical, the SME places absolute trust in their accountant contact at the firm. If a partner of the firm refers a client to me, that client will generally accept that recommendation based on the trust the SME has in the ability of that partner" (AAus04)).

Most SME respondents indicated that trust is won by proving ability, showing empathy and over time building a relationship which can be relied upon. As one SME owner-manager pointed out, “... [R]eputation leads to trust, networking leads to validation of the reputation" (SMEAus03).

\subsection{Selling discretionary services - Is restructuring required for the next generation of accounting firms?}

Our findings suggest that in general, accountants do not market their services strongly to prospective clients. Instead, most new work is derived from referrals, either from internal partners or from the SME network of contacts.

As one accountant said "I'm not a particularly gregarious character who goes out and woos my clients with charisma. More work comes my way due to my work ethic" (AAus03). This raises the question of whether or not the accounting profession should and could raise their levels of service marketing. Is there any point in providing sales training for accountants in order to increase their volume of other services business? This scenario may be counter-productive and requires the accountant to play a role "out of type", a role they may not be suited for and a role that may lead to breaching the very foundations of trust that the SME requires from their accountant as trusted adviser.

As professional advisers, for some accountants being a sales person of services was an anathema. For example, one accountant said "In identifying the opportunity [for advice] salesmanship plays no part, it's about analysing the SME requirements". (AAus02) This 
view was confirmed by another accountant who said "I don't knock on doors! It does not have the same credibility of a referral attached to it. Salesmanship in our business extends to the way you present yourself in terms of your ability, objectivity and ethics. It's not a hard sell of the services but a hard sell of you as someone with ability, credibility, integrity and ethics". (AAus04)

Similar attributes of trustworthiness and a reluctance to do the hard sell were also found amongst financial advisers. Thus a reluctance to become more pro-active in promoting services was not the exclusive domain of accountants.

Given the unpopularity of a significantly raised profile of accountancy services through marketing techniques, how could the accountancy profession develop for the future? One possibility is that accounting firms dealing in the SME market restructure in order to align their services closer to client needs. This may also limit the amount of other services work that is leaked to other professional advisers. As one accountant said "To understand their [ie the client's] industry is really hard when you have 40-50 clients basically across every industry and its hard to be an expert in them all, probably of all things clients say they want it's the hardest [to meet]" (FAAus01). This view was reinforced by one SME who identified the limitations of smaller practices in particular "They [the accountant] could be more specialised in certain areas that can truly offer advice rather than trying to be jack of all trades" (SMEAus04).

Does this analysis lead us to conclude that the accounting firm could be restructured to better suit SME needs and the increasing desire for specialised services? Could it be possible that 'Business Development Managers' are required to be employed by accounting firms to communicate with SME clients to better understand and deliver other services? As one accountant speculated "...accountants don't say enough about what services they can offer" and proffered "[there are] two types of salespeople - openers and closers. Accountants are not openers. So we employed tele-marketers who are experts at opening and we found a lot of people were interested to know more" (AAus05).

The research implies that it is worthwhile pursuing the complex issue of the marketing of external accountants' non-compliance services to the SME market. This may involve much more than tele-marketing, much more intrinsic than just making a phone call and passing it on. The SME owner-manager may desire a more continuous and solid 
relationship, that involves clear communication. Similarly, if accountants are not good communicators as found from the results of the interviews, then this issue must be investigated further with implications drawn out for practice.

\section{CONCLUSIONS AND RECOMMENDATIONS}

The primary aims of this research are to provide a detailed understanding of the nature of services provided by external accountants to SMEs, examine the intervening role of competence, trust and ethics in the demand for business advice, and explore other factors influencing SMEs purchase of business advice to inform the underdeveloped extant literature. The results confirm that owner-managers tend to purchase additional non-compliance business services from their accountant. On the supply side, it is clear that accountants sell other services off the back of traditional statutory or compliance services. The existing relationship, based on the purchase of compliance services, appears to provide a foundation from which the external accountant might also sell business advisory services. Accountants were conscious of finding the right balance between raising awareness that they sell 'additional' business services and not marketing these too aggressively. In fact, most accountants agreed they tend not to actively sell advisory services to their SME clients. From the accountants' perspective the provision of advice tends to emerge following interactions through compliance work.

Both SMEs and external accountants agreed that additional advice were frequently taken up in the early years of the business as the owner-manager faced many new challenges and had not yet developed the necessary business expertise. SME owner-managers agreed they are seeking a confidante to provide advice over and above compliance services. Being a business owner is often a lonely and isolated life. However the confidante may or may not be the accountant.

SMEs expressed mixed views as to whether external accountants are capable of providing useful business advice, yet all external accountants interviewed perceived themselves as having the necessary skills to provide business advice. The result suggests that an expectation gap exists between what the SME owner needs and what the external accountant is able to supply. All SME owners used multiple advisers and not all SME's will use an external accountant for other services. The market for business advice is highly competitive and while external accountants are well placed to also acquire this work, they 
need to convince clients they have the necessary business expertise thereby closing the current expectation gap.

An important factor which determines whether the accountant is perceived to be competent to provide business advice is their industry experience. There were mixed views amongst owner-managers on whether the accountant had to possess specific industry experience for them to be able to provide advice. Where there is demand for business advice emanating from a need to enhance competitive advantage, the type of adviser sought by an SME needs to have highly specialised industry knowledge. All SME respondents indicated that they purchase business advice, but not all SMEs used an external accountant. The market for business advice is highly competitive and while external accountants are well placed to also acquire this work, they need to convince clients they have the necessary business expertise.

Most accountants indicated they have an existing relationship with the SME built on competency, empathy and trust. Hence, accountants appear to be in a good position to supply other services to their SME clients. Referrals imply competency and competence was a given (assumed), while trust was earned over time. Most accountants suggested business advice is not sought proactively but emerges primarily from interactions through compliance work. Relationship building leads to provision of services following "Milestone Events". Such services might be associated with succession, family conflict, changes to regulation, etc. But accountants are generally not found to be good at communicating the business advisory services they can potentially offer. As a result, much of the other services are captured by other professional advisers.

A major factor that drives demand for advice is the personality of the SME owner. We identify and propose two distinct types of personalities among SME owners. The first personality type we described as a "self-directed individual" who is confident to rely solely on their own judgement and are, therefore, less likely to buy advice believing they processed the necessary business expertise. These individuals tended to buy advice only following a milestone event such as changes in regulation, purchase or sale of the business or business segments, retirement or successions, or changing family circumstances.

The second distinct personality group we labelled as "validators", who like to affirm decisions by seeking confirmatory advice. This group looks to developing their confidence in 
a decision path over time and thus they tend to make more considered decisions. This group is also more likely to seek ongoing advice. As one SME said "we recognise we need help" and 'anyone who thinks they have all the answers is a 'dill'. Small business can become very cloistered very quickly [and] you can become blinkered and convince yourself you're right about things when actually you don't have the knowledge base to make decisions" (SMEAus01).

An important dimension of business advisory services is the view that the accountant is a "trusted partner" providing personal relationship and is a confidante to the ownermanager. Fieldwork results highlight a number of dimensions required for the development of trust. Trust is typically built through an on-going relationship between the accountant and the SME client through the provision of compliance services, and is developed over time. Social rapport is required as a minimum to allow a relationship to develop and for trust to be established. While there needs to be an element of shared values for social rapport, in most cases it is not necessary for there to be socialising outside the business relationship for social rapport to be effective. In addition, both accountants and their SME clients emphasised the critical importance of empathy to the development of successful client relationship and the provision of business advisory services. Empathy involves understanding and genuinely caring about the clients' interests and requires the accountant to take time to genuinely understanding the clients' business and personal needs. These results demonstrate that SME owners exhibit both calculative and affective trust behaviours, that is, the relationship with the accountant is based on diminishing information asymmetries and uncertainties as well as emotional inputs derived from repeated interactions and information acquired over time.

There was a consensus among interviewees that accountants do not market their services strongly to prospective clients. In contrast to many of their competitors for business services, accountants are not particularly gregarious characters and charismatic in the sale of their services. Instead, most new work is derived from referrals, either from internal partners or from the SME network of contacts or derived demand from compliance work.

This research specifically examines the role of trust and competence in SMEs seeking business advice. While extant literature has considered trust and competence in business relations between larger organisations, evidence of the importance of trust and competence within the SME context in relation to business advice provided by external accountants is both scant and underdeveloped (e.g., Smith et al., 1995; Sharif et al., 2005; Rousseau et al., 
1998; Zaheer et al., 1998). We demonstrate SME clients will tend to purchase business advice only after they have nurtured a relationship with their business adviser(s) to minimize uncertainty while simultaneously recognizing that a SMEs' competitive advantage can lie in the professional relationship the owner-manager builds up with his/her external accountant. It is precisely through such a relationship, which is 'earned' by building up trust, that the SME owner-manager can tap into the external accountant's expertise and knowledge of business processes in different sectors of the economy that can provide strategic support to the bundle of valuable resources at the owner-managers' disposal.

Finally, we find no evidence that concerns about auditor independence post Enron emanating from regulatory change affecting public interest entities have influenced the likelihood of external accountants also provide business advice in the SME environment.

\subsection{Limitations of the study}

This research has drawn on evidence collected in face-to-face interviews with a small sample of accountants, financial advisers and SME owner-managers in the UK and Australia. The limited numbers and absence of symmetry in the UK and Australian fieldwork cases mean that caution must be exercised in generalising from the results or providing a countrycomparative analysis. Our results pave the way for a more extensive study of the accountantSME relationship in the provision of business advice. While results indicate that the nature of business advice provided by external accountants appears to be consistent with their traditional expertise, future research could explore this contention.

\subsection{Implications for Practice}

The evidence presented shows that for a SME-account relation to successfully exist, accountants are not required to "hard sell" their services and accountant have not been found to be good at hard selling. However in order to respond to the increasing demand for specialist services and adding value beyond compliance services from their SME clients, it may be argued that the accountant needs to create a pathway to enable them to capture the market share that is available via a pre existing relationship of trust. SME owners demanding business advice do not necessarily seek out their external accountant for this service. Some SME's have multiple business advisers which demonstrate the market for business advice is competitive and creates a challenge for the accounting profession. An common technique 
used by accountants to communicating their broader expertise to clients was through the use of networks or forums for SME owner-managers. There may be scope for small and medium size accountant to enhance their business acumen by reorganising their practice in order to develop greater industry experience.

Many accountants are in a good position to supply the SME's demand for more broad ranging business advice which may be built upon and be integrated with information gleaned from compliance services. By using the same supplier, SMEs may benefit from economies of delivery and information costs (e.g., Bennett and Smith, 2002). However, many other professional service providers may be more proactive in marketing their services to SME owners and thus capturing market-share. This leads to the question whether or not should accountants overtly market their services. This then begs the question: "will this lead to accountants not being seen as the trusted adviser that has empathy for the SME business"? Might the SME become suspicious of the motivations of the accountant? Overt marketing has not stopped other advisers used by the SMEs displaying underlying attributes of competency, empathy and trust. Future research might explore these questions. 


\section{REFERENCES}

Accounting Professional and Ethical Standards (February 2008). Compiled APES 110 Code of Ethics for Professional Accountants. Handbook of International Auditing, Assurance and Ethics Pronouncements. International Ethics Standards Board for Accountants: International Federation of Accountants (IFAC).

Achrol, R.S. (1997). Changes in the theory of interorganizational relations in marketing: toward a network paradigm. Journal of the Academy of Marketing Science, 25(2), pp. 56-71.

Andaleeb, S.S. (1992). The trust concept: research issues for channels of distribution. Research in Marketing, 11, pp. 1-34.

THE AUSTRALIAN BUSINESS REGISTER, (June 2001; ABS CATALOGUE NO. 1369.0.55.001).

Barney, J.B. (1991) Firm resources and sustained competitive advantage. Journal of Management, 17(1), 99-120.

Barney, J.B. (2001) Resource-based theories of competitive advantage: A ten-year retrospective on the resource-based view. Journal of Management, 27, 643-650.

Barney, J.B. and Hansen, M.H. (1994). Trustworthiness as a source of competitive advantage. Strategic Management Journal, 15, pp. 175-190.

Bennett, R.J. and Robson, P.J. (2005) The adviser-SME client relationship: Impact, satisfaction and commitment. Small Business Economics 25:255-271.

Bennett, R.J. and Smith, C. (2004). The influence of location and distance on the supply of business advice. Entrepreneurship and Regional Development, 11(2), pp. 155-180.

Bennett, R. J., P. J. A. Robson, and W.J.A. Bratton. 2001. The influence of location on the use by SMEs of external advice and collaboration. Urban Studies 38(9): 1531-57.

Bennett, R.J. and Robson, P.J. (1999). The use of external business advice by SMEs in Britain. Enterprise and Regional Development 11:155-180

Berry, L.L. (2002). Relationship marketing of services - perspectives from 1983 to 2000. Journal of Relationship Marketing, 1(1), pp.59-77.

Berry, L.L. (1995). Relationship marketing of services - growing interest, emerging perspectives. Journal of the Academy of Marketing Science, 23(Fall), 4, 236-245.

Berry, L. L. (1983). Relationship marketing. In L. L. Berry, G. L. Shostack, \& G. Upah. (Eds.), Emerging Perspectives on Services Marketing (pp. 25-28). Chicago, IL: American Marketing Association.

Berry, A.J. and Sweeting, R. (2006) The effect business advisers on the performance of SMEs. Journal of Small Business and Enterprise Development 13(1): 33-47.

Blackburn, R., Eadson, W., Lefebvre, R. And Gans, P. (2006) SMEs, regulation and the role of the accountant, ACCA Research Report, No. 96, ACCA, London. 
Cameron, A. (1995) Public accountants' fees and small business clients. Accounting Forum. 19(1):13-28.

Carey, P. and Tanewski, G.A. (2009). The provision of business advice by external accountants to the SME clients: agency theory, relational marketing and resource dependence. Working Paper, Monash University.

Carey P.J., Subramaniam N., and K Chua. (2006) Outsourcing internal audit in Australia. Accounting and Finance. 46 (1):11-30.

Carey, P., Simnett, R., and Tanewski, G. (2005) Providing business advice to small and medium sized enterprises. Report prepared for CPA Australia. (July).

Carey, P., Simnett, R., and Tanewski, G. (2001) Voluntary demand for internal and external auditing by family businesses. Auditing: A Journal of Theory of Practice, 19(2000 Supplement): $37-51$.

Cassar, G. and Ittner, C. D. (2008) Initial Retention of External Accountants in Start-up Ventures, European Accounting Review

Chell, E. and Baines, S. (2000) Networking, Entrepreneurship and Microbusiness Behavior, Entrepreneurship and Regional Development 12(3): 195-215.

Crosby, L.A., Evans, K.R. and Cowles, D. (1990). Relationship quality in services selling: an interpersonal influence perspective. Journal of Marketing, 54(July), pp. 68-81.

Curran, J. and R.A. Blackburn (1994) Small firms and local economic networks: The death of the local economy? London: Paul Chapman/Sage.

Deakins, D., Logan, D. and Steele, L. (2001) 'The Financial Management of the Small Enterprise', ACCA Research Report No. 64. London: The Association of Chartered Certified Accountants, Certified Accountants Educational Trust.

Deakins, D. Morrison, A, and L. Galloway. (2002) Evolution, financial management and learning in small firms. Journal of Small Business and Enterprise Development. 9(1): 7-16.

Department for Business Innovation and Skills (2009) Enterprise Directorate Analytical Unit, accessed July, http://www.berr.gov.uk/whatwedo/enterprise/enterprisesmes/researchand-statistics/statistics/page38573.html

Doving, E., Gooderham, P.N., Morrison, A., and O Nordhaug. (2004) Small firm accountants as business advisors: Accounting for the differences in their provision of business advisory services. EAA Conference. Prague. April.

Doving, E. And Gooderham, P.N. (2008) 'Dynamic Capabilities as antecedents of the scope of related diversification: the case of small firm accountancy practices', Strategic Management Journal, 29: 841-857.

European Commission (2003) The New SME Definition, User guide and model declaration (http://ec.europa.eu/enterprise/enterprise_policy/sme_definition/sme_user_guide.pdf

Firth, M. (1997), 'The Provision of Non-audit Services by accounting firms to their audit clients', Contemporary Accounting Research, Vol. 14, Nos. 2: 1-21 
Fogarty, T.J., Radcliffe, V.S., and D.R. Campbell (2006) Accountancy before the fall. The AICPA vision project and related professional enterprises. Accounting Organizations and Society. 31: 1-25.

Gooderham, P.N., Tobiassen, A., Doving, E., and O. Nordhaug. (2004) Accountants and sources of business advice for small firms. International Small Business Journal. 22(1):5-22.

Greenwood, R., Suddaby, R. and C.R. Hinings (2002) Theorizing change: The role of professional associations in the transformation of institutional fields. Academy of Management Journal. 45(1):58-80.

Grönroos, C. (1990). Service Management and Marketing: Managing the Moments of Truth in Service Competition, Lexington Books, Lexington, MA.

Holmes, S and Nicholls, D (1989) Modelling the accounting information requirements of small businesses. Accounting and Business Research 19(74): 143-150.

Holmes, S. Kelly, G. and R, Cunningham (1991) The small firm information cycle: A reappraisal. International Small Business Journal 9(2): 41-53.

Houghton, K.A., and C.Ikin (2001) Auditor provided non-audit services: Modelling fees and willingness to buy. Working paper. ANU.

Jennings, P. and Beaver, G. (1997) 'The Performance and Competitive Advantage of Small Firms: A Management Perspective', International Small Business Journal 15(2): 63-75.

Johnson, S. ,Webber, D.J., and W. Thomas. 2007. Which SMEs use external business advice? A multivariate subregional study. Environment and Planning (39): 1981-97.

Kirby, D.A., Najak, B., and F Greene (1998) Accounting for growth: Ways accountants can add value to small business. The Research Board. ICEW. London.

Kirby, D.A. and King, S.H. (1997) Accountants and small business development: Filling the expectation gap. The Services Industries Journal 17(2): 294-304.

Kitching, J. and Blackburn, R. (2002) The nature of training and motivation to train in small firms, London, UK : Department for Education and Skills.

Knights, D., Noble, F., Vurdubakis, T., and Willmott, H. (2001). Chasing shadows: control, virtuality and the production of trust. Organization Studies, 22(2), pp.311-336.

Martin, C. (2004) Accountancy practices and the provision of ownership succession advice, ACCA Research Report RR85, ACCA, London.

Mayer, R.C., Davis, J.H, and Schoorman, F.D. (1995). An integrative model of organizational trust. Academy of Management Review, 20(3), pp. 709-734.

Parasuraman, A., Zeithaml, V.A., and Berry, L.L. (1985). A conceptual model of service quality and its implications for future research. Journal of Marketing, 49(Fall), pp. 4150 . 
Parasuraman, A., Zeithaml, V.A., and Berry, L.L. (1988). SERVQUAL: multiple-item scale for measuring consumer perceptions of service quality. Journal of Retailing, 64(Spring), pp. 12-40.

Parker, L. (2001). Back to the future: The broadening accounting trajectory. British Accounting Review, 33, 421-453.

Price, L.L., Arnould, E.J. and Tierney, P. (1995). Going to extremes: managing and assessing provider performance. Journal of Marekting, 59(April), pp. 83-97.

Ram, M. and Carter, S. (2001). Smaller practices in profile. London: Association of Chartered Certified Accountants.

Robson, P.J.A., and R J. Bennett. 2000. SME growth: The relationship with business advice and external collaboration. Small Business Economics 15(3):193-208.

Rousseau, D. M., Sitkin, S. B., Burt, R. S., \& Camerer, C. (1998). Not so different after all: A cross-discipline view of trust. Academy of Management Review, 23: 393-404.

Ryals, L. and A. Payne. 2001. Customer relationship management in financial services: towards information-enabled relationship marketing. Journal of Strategic Marketing 9(1): 3-27.

Turnbull, P.W. and Moustakatos, T. (1996). Marketing and investment banking 2: relationships and competitive advantage. International Journal of Bank Marketing, 14(2), pp. 38-49.

Tyler, K. and Stanley, E (2007) The role of trust in financial services business relationships. Journal of Services Marketing, 21(5), 334-344.

Zineldin, M. (1995). Bank-company interactions and relationships: some empirical evidence. International Journal of Bank Marketing, 13(2), pp. 30-40. 